\title{
Alkaloids and Phenolic Compounds from Sida rhombifolia L. (Malvaceae) and Vasorelaxant Activity of Two Indoquinoline Alkaloids
}

\author{
Otemberg Souza Chaves ${ }^{1}$, Yanna Carolina Ferreira Teles ${ }^{2,3}$, \\ Matheus Morais de Oliveira Monteiro ${ }^{1}$, Leônidas das Graças Mendes Junior ${ }^{1}$, \\ Maria de Fátima Agra ${ }^{1}$, Valdir de Andrade Braga ${ }^{1}$, Tânia Maria Sarmento Silva ${ }^{4}$ \\ and Maria de Fátima Vanderlei de Souza ${ }^{1,2, *}$ \\ 1 Post Graduation Program in Bioactive Natural and Synthetic Products, Health Sciences Center, \\ Federal University of Paraíba, 58051-970 João Pessoa, PB, Brazil; otembergsc@ltf.ufpb.br (O.S.C.); \\ monteirommo@gmail.com (M.M.d.O.M.); leonidasjunior@ltf.ufpb.br (L.d.G.M.J.); \\ agramf@ltf.ufpb.br (M.d.F.A.); valdir@cbiotec.ufpb.br (V.d.A.B.) \\ 2 Post Graduation in Development and Technological Innovation in Medicines, \\ Federal University of Paraiba, 58051-900 João Pessoa, PB, Brazil; yannateles@gmail.com \\ 3 Department of Chemistry and Physics, Agrarian Sciences Center, Federal University of Paraíba, \\ 58397-972 Areia, PB, Brazil \\ 4 Department of Molecular Sciences, Federal Rural University of Pernambuco, Campus Dois Irmãos, \\ 52171-900 Recife, PE, Brazil; sarmentosilva@gmail.com \\ * Correspondence: mfvanderlei@ltf.ufpb.br; Tel.: +55-83-3216-7351
}

Academic Editor: Derek J. McPhee

Received: 12 November 2016; Accepted: 26 December 2016; Published: 6 January 2017

\begin{abstract}
The follow-up of phytochemical and pharmacological studies of Sida rhombifolia L. (Malvaceae) aims to strengthen the chemosystematics and pharmacology of Sida genera and support the ethnopharmacological use of this species as hypotensive herb. The present work reports phytoconstituents isolated and identified from aerial parts of S. rhombifolia by using chromatographic and spectroscopic methods. The study led to the isolation of scopoletin (1), scoporone (2), ethoxy-ferulate (3), kaempferol (4), kaempferol-3-O- $\beta$-D-glycosyl- $6^{\prime \prime}$ - $\alpha$-D-rhamnose (5), quindolinone (6), 11-methoxy-quindoline (7), quindoline (8), and the cryptolepine salt (9). The alkaloids quindolinone (6) and cryptolepine salt (9) showed vasorelaxant activity in rodent isolated mesenteric arteries.
\end{abstract}

Keywords: Sida rhombifolia; Malvaceae; indoquinoline alkaloids; vasorelaxant activity

\section{Introduction}

The Malvaceae family Juss. has predominantly pantropical distribution, including about 250 genera and 4200 species [1]. In Brazil, 70 genera are found widely spread, from which nine are considered endemic [2]. The Sida genus is considered native to Brazil and presents 95 species [3]. Many Sida species are used in American, African, and Asian countries, showing good efficacy in health disorders [4].

Sida rhombifolia L. is popularly known in Brazil as "matapasto", "guanxuma", and "relógio". It is used in Indian popular medicine against hypertension, diabetes, and for the treatment of gout $[5,6]$. Previous studies have reported chemical constituents isolated from this species, including steroids, chlorophyll derivatives, flavonoids, alkaloids, $\beta$-phenylethylamines, and carboxylated tryptamines [4,5].

In order to strengthen chemosystematics and pharmacology of Sida genera, as well as to support the popular medicinal use of this plant, the phytochemical study of S. rhombifolia (Malvaceae) was 
continued. The study led to the isolation of nine secondary metabolites from the aerial parts of S. rhombifolia. Additionally, the vasorelaxant activity of two isolated alkaloids was demonstrated, justifying the popular use of the species against arterial hypertension.

\section{Results}

\subsection{Identification of Isolated Compounds}

The isolated and identified compounds from aerial parts of S. rhombifolia are showed in Figure 1. The NMR data of compound $7\left({ }^{1} \mathrm{H},{ }^{13} \mathrm{C}\right.$, Heteronuclear Single Quantum Correlation-HSQC, Heteronuclear Multiple Bond Correlation-HMBC, and Nuclear Overhauser Spectroscopy-NOESY) are presented in Table 1. Spectral data from the other compounds are also presented.
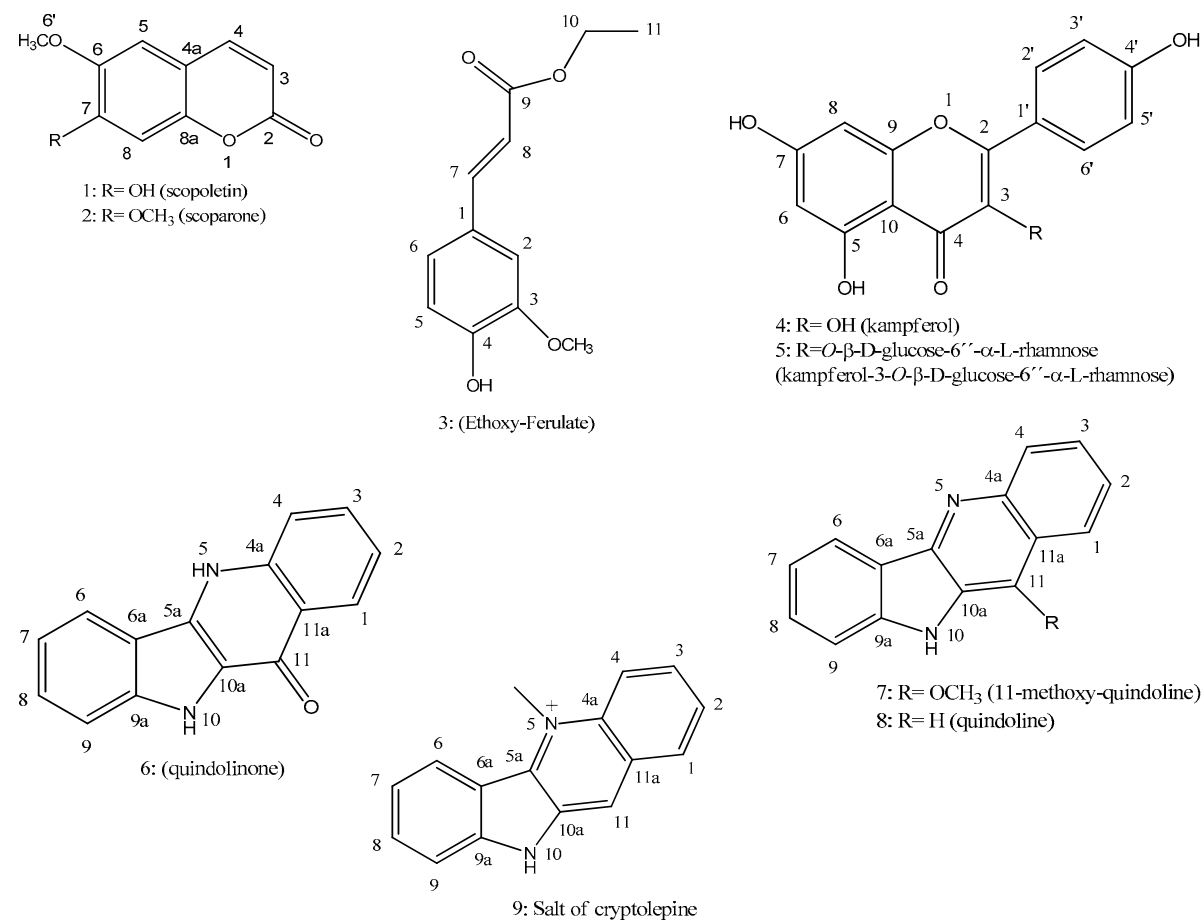

Figure 1. Structure of compounds isolated from S. rhombifolia (Malvaceae).

Table 1. NMR data $\left({ }^{1} \mathrm{H},{ }^{13} \mathrm{C}, \mathrm{HMQC}, \mathrm{HMBC}\right.$ and NOESY) of compound 7 ( $\delta$, DMSO- $d_{6}, 500$ and $\left.125 \mathrm{MHz}\right)$.

\begin{tabular}{|c|c|c|c|c|c|c|}
\hline \multirow{2}{*}{$\mathrm{H} / \mathrm{C}$} & \multicolumn{2}{|l|}{ HSQC } & \multicolumn{3}{|c|}{ НМВС } & \multirow[t]{2}{*}{ NOESY } \\
\hline & $\delta_{\mathrm{H}}$ & $\delta_{C}$ & ${ }^{2} J$ & ${ }^{3} \mathrm{~J}$ & ${ }^{4} J$ & \\
\hline 1 & $8.30(\mathrm{bd}, J=8.45 \mathrm{~Hz}, 1 \mathrm{H})$ & 121.3 & - & C-11/C-4a/C-3 & - & $\mathrm{OCH}_{3} / \mathrm{H}-2$ \\
\hline 2 & $7.58(\mathrm{bt}, J=7.55 \mathrm{~Hz}, 1 \mathrm{H})$ & 124.5 & - & C-4/C-11a & - & H-1 \\
\hline 3 & $7.70(\mathrm{bt}, J=7.45 \mathrm{~Hz}, 1 \mathrm{H})$ & 127.1 & - & C- $4 \mathrm{a}$ & - & $\mathrm{H}-4$ \\
\hline 4 & $8.18(\mathrm{bd}, J=8.5 \mathrm{~Hz}, 1 \mathrm{H})$ & 127.9 & - & C-2/C-11a & - & $\mathrm{H}-3$ \\
\hline $4 \mathrm{a}$ & - & 143.9 & - & - & - & - \\
\hline $5-\mathrm{N}$ & - & - & - & - & - & - \\
\hline $5 a$ & - & $126.7^{*}$ & - & - & - & - \\
\hline $6 a$ & - & 121.7 & - & - & - & - \\
\hline 6 & $8.37(\mathrm{bd}, J=7.85 \mathrm{~Hz}, 1 \mathrm{H})$ & 121.4 & & C-9a/C-8 & & H-7 \\
\hline 7 & $7.30(\mathrm{bt}, J=7.02 \mathrm{~Hz}, 1 \mathrm{H})$ & 119.6 & C-8/C-6 & C-9 & C-9a & H-6/H-8 \\
\hline 8 & $7.63(\mathrm{bt}, J=7.6 \mathrm{~Hz}, 1 \mathrm{H})$ & 130.0 & C-7 & $C-9 a$ & - & H-7 \\
\hline 9 & $7.64(\mathrm{bd}, J=7.1 \mathrm{~Hz}, 1 \mathrm{H})$ & 112.0 & $C-9 a$ & C-7 & - & - \\
\hline $9 a$ & - & 143.9 & - & - & - & - \\
\hline $10-\mathrm{NH}$ & $11.50(\mathrm{~s}, 1 \mathrm{H})$ & & - & - & - & $\mathrm{OCH}_{3} / \mathrm{H}-9$ \\
\hline $10 a$ & - & $125.6 *$ & - & - & - & - \\
\hline 11 & - & 146.1 & - & - & - & - \\
\hline $11 \mathrm{a}$ & - & 120.3 & - & - & - & - \\
\hline $\mathrm{OCH}_{3}$ & $4.39(\mathrm{~s}, 3 \mathrm{H})$ & 60.7 & - & C-11 & - & $\mathrm{H}-1 / 10-\mathrm{NH}$ \\
\hline
\end{tabular}




\section{Spectral Data}

2H-1-Benzopyran-2-one, 7-hydroxy-6-methoxy (Scopoletin, 1). Colourless crystal: ${ }^{1} \mathrm{H}-\mathrm{NMR}(500 \mathrm{MHz})$ $\left(\mathrm{CD}_{3} \mathrm{OD}\right)$ 8: $6.21(\mathrm{~d}, J=9.4 \mathrm{~Hz}, 1 \mathrm{H}, \mathrm{H}-3), 7.86(\mathrm{~d}, J=9.4 \mathrm{~Hz}, 1 \mathrm{H}, \mathrm{H}-4), 7.12(\mathrm{~s}, 1 \mathrm{H}, \mathrm{H}-5), 6.77(\mathrm{~s}, 1 \mathrm{H}$, $\mathrm{H}-8)$ and $3.91\left(\mathrm{~s}, 3 \mathrm{H}, \mathrm{H}-6^{\prime}\right) .{ }^{13} \mathrm{C}-\mathrm{NMR}(125 \mathrm{MHz})\left(\mathrm{CD}_{3} \mathrm{OD}\right) \delta: 164.0$ (C-2), 112.6 (C-3), 146.0 (C-4), 112.5 (4a), 110.0 (C-5), $147.0(\mathrm{C}-6), 152.9$ (C-7), 103.9 (C-8), $151.4(8 \mathrm{a})$ and $56.8\left(6^{\prime}-\mathrm{OCH}_{3}\right)$. In agreement with literature [7].

2H-1-Benzopyran-2-one, 6,7-dimethoxy (Scoparone, 2). Colourless crystal: ${ }^{1} \mathrm{H}-\mathrm{NMR}(200 \mathrm{MHz})\left(\mathrm{CDCl}_{3}\right)$ $\delta: 6.25(\mathrm{~d}, J=9.48 \mathrm{~Hz}, 1 \mathrm{H}, \mathrm{H}-3), 7.37$ (d, J = 9.48 Hz, 1H, H-4), 6.83 (s, 1H, H-5), 6.81 (s, 1H, H-8), $3.92(\mathrm{~s}$, $\left.3 \mathrm{H}, 6^{\prime}-\mathrm{OCH}_{3}\right)$ and $3.89\left(\mathrm{~s}, 3 \mathrm{H}, 7^{\prime}-\mathrm{OCH}_{3}\right) .{ }^{13} \mathrm{C}-\mathrm{NMR}(50 \mathrm{MHz})\left(\mathrm{CDCl}_{3}\right) \delta: 161.4(\mathrm{C}-2), 113.4(\mathrm{C}-3), 143.3$ (C-4), 111.3 (4a), 107.8 (C-5), 146.2 (C-6), 152.7 (C-7), 99.9 (C-8), 149.9 (C8a), $56.36\left(6^{\prime}-\mathrm{OCH}_{3}\right)$ and 56.32 $\left(7^{\prime}-\mathrm{OCH}_{3}\right)$. In agreement with literature [8].

2-Propenoic acid, 3-(4-hydroxy-3-methoxyphenyl)-ethyl ester (Ethoxy-ferulate, 3). Yellowish oil: ${ }^{1} \mathrm{H}-\mathrm{NMR}$ $(500 \mathrm{MHz})\left(\mathrm{CDCl}_{3}\right) \delta: 7.03(\mathrm{~d}, J=2.0 \mathrm{~Hz}, 1 \mathrm{H}, \mathrm{H}-2), 6.91(\mathrm{~d}, J=8.15 \mathrm{~Hz}, 1 \mathrm{H}, \mathrm{H}-5), 7.07$ (dd, J = 8.15; $2.0 \mathrm{~Hz}, 1 \mathrm{H}, \mathrm{H}-6), 7.61$ (d, J = $15.9 \mathrm{~Hz}, 1 \mathrm{H}, \mathrm{H}-7), 6.29$ (d, J = $15.9 \mathrm{~Hz}, 1 \mathrm{H}, \mathrm{H}-8), 4.26(\mathrm{q}, J=7.15 \mathrm{~Hz}, 2 \mathrm{H}$, $\mathrm{H}-10), 1.33(\mathrm{t}, J=7.15 \mathrm{~Hz}, 3 \mathrm{H}, \mathrm{H}-11)$ and $3.92\left(\mathrm{~s}, 3 \mathrm{H}, 3^{\prime}-\mathrm{OCH}_{3}\right) .{ }^{13} \mathrm{C}-\mathrm{NMR}(125 \mathrm{MHz})\left(\mathrm{CDCl}_{3}\right) \delta: 127.2$ (C-1), 109.4 (C-2), 146.9 (C-3), 148.0 (C-4), 114.8 (C-5), 123.1 (C-6), 144.7 (C-7), 115.8 (C-8), 167.4 (C-9), $60.5(\mathrm{C}-10), 14.5(\mathrm{C}-11)$ and $56.10\left(3^{\prime}-\mathrm{OCH}_{3}\right)$. In agreement with literature [7].

4H-1-Benzopyran-4-one, 3,5,7-trihydroxy-2-(4-hydroxyphenyl) (Kaempferol, 4). Yellow powder: ${ }^{1} \mathrm{H}-\mathrm{NMR}$ $(500 \mathrm{MHz})\left(\mathrm{CD}_{3} \mathrm{OD}\right) \delta: 6.18(\mathrm{~d}, J=2.00 \mathrm{~Hz}, 1 \mathrm{H}, \mathrm{H}-6), 6.39(\mathrm{~d}, J=2.00 \mathrm{~Hz}, 1 \mathrm{H}, \mathrm{H}-8), 8.08(\mathrm{~d}, J=8.9 \mathrm{~Hz}$, $\left.2 \mathrm{H}, 2^{\prime} / 6^{\prime}\right)$ and $6.90\left(\mathrm{~d}, J=8.9 \mathrm{~Hz}, 2 \mathrm{H}, 3^{\prime} / 5^{\prime}\right) .{ }^{13} \mathrm{C}-\mathrm{NMR}(125 \mathrm{MHz})\left(\mathrm{CD}_{3} \mathrm{OD}\right) \delta: 148.0(\mathrm{C}-2), 137.1(\mathrm{C}-3)$, 17.3 (C-4), 162.5 (C-5), 99.3 (C-6), 165.6 (C-7), 94.4 (C-8), 158.2 (C-9), 103.7 (C-10), 123.7 (C-1'), 130.6 $\left(\mathrm{C}-2^{\prime} / \mathrm{C}-6^{\prime}\right), 116.3\left(\mathrm{C}-3^{\prime} / \mathrm{C}-5^{\prime}\right)$ and $160.5\left(\mathrm{C}-4^{\prime}\right)$. In agreement with literature [9].

4H-1-Benzopyran-4-one, 3-[[6-O-(6-deoxy- $\alpha$-L-mannopyranosyl)- $\beta$-D-galactopyranosyl]oxy]-5,7-dihydroxy-2(4-hydroxyphenyl) (Kaempferol-3-O- $\beta$-D-glucose- $6{ }^{\prime \prime}-\alpha$-D-rhamnose, 5). Yellow powder: ${ }^{1} \mathrm{H}-\mathrm{NMR}$ $(500 \mathrm{MHz})\left(\mathrm{CD}_{3} \mathrm{OD}\right) \delta: 6.16(\mathrm{~d}, J=2.0 \mathrm{~Hz}, 1 \mathrm{H}, \mathrm{H}-6), 6.34(\mathrm{~d}, J=2.0 \mathrm{~Hz}, 1 \mathrm{H}, \mathrm{H}-8), 8.04(\mathrm{~d}, J=8.89 \mathrm{~Hz}$, $\left.2 \mathrm{H}, 2^{\prime} / 6^{\prime}\right), 6.87\left(\mathrm{~d}, J=8.89 \mathrm{~Hz}, 2 \mathrm{H}, 3^{\prime} / 5^{\prime}\right), 5.08\left(\mathrm{~d}, J=7.48 \mathrm{~Hz}, 1 \mathrm{H}, \mathrm{H}-1^{\prime \prime}\right), 3.38-3.82\left(\mathrm{~m}, 6 \mathrm{H}, \mathrm{H}-2^{\prime \prime}\right.$ a H-6 $\left.{ }^{\prime \prime}\right)$, 4.50 (bs, $\left.1 \mathrm{H}, \mathrm{H}-\mathrm{-}^{\prime \prime \prime}\right), 3.38-3.82\left(\mathrm{~m}, 5 \mathrm{H}, \mathrm{H}-2^{\prime \prime \prime}\right.$ a H-5 $\left.{ }^{\prime \prime \prime}\right)$ and $1.12\left(\mathrm{~d}, J=6.08 \mathrm{~Hz}, 3 \mathrm{H}, \mathrm{H}-6^{\prime \prime \prime}\right) .{ }^{13} \mathrm{C}-\mathrm{NMR}$ (125 MHz) (CD $\left.{ }_{3} \mathrm{OD}\right)$ 8: 159.4 (C-2), 137.4 (C-3), 179.3 (C-4), 162.8 (C-5), 100.0 (C-6), 166.6 (C-7), 94.9 (C-8), 158.5 (C-9), $105.5(\mathrm{C}-10), 122.6\left(\mathrm{C}-1^{\prime}\right), 132.3\left(\mathrm{C}-2^{\prime} / 6^{\prime}\right), 116.1\left(\mathrm{C}-3^{\prime} / 5^{\prime}\right), 161.4\left(\mathrm{C}-6^{\prime}\right), 104.5\left(\mathrm{C}-1^{\prime \prime}\right)$, $71.3\left(\mathrm{C}-2^{\prime \prime}\right), 78.0\left(\mathrm{C}-3^{\prime \prime}\right), 75.6\left(\mathrm{C}-4^{\prime \prime}\right), 69.7\left(\mathrm{C}-5^{\prime \prime}\right), 68.5\left(\mathrm{C}-6^{\prime \prime}\right), 102.3\left(\mathrm{C}-1^{\prime \prime \prime}\right), 72.0\left(\mathrm{C}-2^{\prime \prime \prime}\right), 72.2\left(\mathrm{C}-3^{\prime \prime \prime}\right), 77.1$ $\left(\mathrm{C}-4^{\prime \prime \prime}\right), 73.8\left(\mathrm{C}-5^{\prime \prime \prime}\right)$ and $17.9\left(\mathrm{C}-6^{\prime \prime \prime}\right)$. In agreement with literature [10].

11H-Quindolin-11-one-5,10-dihydro (Quindolinone, 6). Yellow powder: ${ }^{1} \mathrm{H}-\mathrm{NMR}(500 \mathrm{MHz})\left(\mathrm{DMSO}-d_{6}\right)$ $\delta: 8.35(\mathrm{dd}, J=8.1,1.2 \mathrm{~Hz}, 1 \mathrm{H}, \mathrm{H}-1), 7.28(\mathrm{td}, J=8.1 ; 6.8 ; 1.0 \mathrm{H} \mathrm{z}, 1 \mathrm{H}, \mathrm{H}-2), 7.68(\mathrm{td}, J=8.3 ; 6.8 ; 1.57 \mathrm{~Hz}$, $1 \mathrm{H}, \mathrm{H}-3), 7.73(\mathrm{dd}, J=8.3 ; 1.0 \mathrm{~Hz}, 1 \mathrm{H}, \mathrm{H}-4), 12.43(\mathrm{~s}, 1 \mathrm{H}, 5-\mathrm{NH}), 8.19(\mathrm{dl}, J=8.0 \mathrm{~Hz}, 1 \mathrm{H}, \mathrm{H}-6), 7.20$ (td, $J=8.0 ; 6.8 ; 1.0 \mathrm{~Hz}, 1 \mathrm{H}, \mathrm{H}-7), 7.47(\mathrm{td}, J=8.3 ; 6.8 ; 1.2 \mathrm{~Hz}, 1 \mathrm{H}, \mathrm{H}-8), 7.52(\mathrm{dt}, J=8.3 ; 1.0 \mathrm{~Hz}, 1 \mathrm{H}, \mathrm{H}-9)$ and $11.67(\mathrm{~s}, 1 \mathrm{H}, 10-\mathrm{NH}) .{ }^{13} \mathrm{C}-\mathrm{NMR}(125 \mathrm{MHz})\left(\mathrm{DMSO}-d_{6}\right) \delta: 125.1(\mathrm{C}-1), 120.4(\mathrm{C}-2), 130.6(\mathrm{C}-3), 117.7$ (C-4), 139.0 (C-4a), 128.8 (C-5a), 115.8 (C-6a), 120.7 (C-6), 118.8 (C-7), 127.3 (C-8), 112.5 (C-9), 138.5 (C-9a), 123.0 (C-10a), 167.3 (C-11) and 122.8 (C-11a). In agreement with literature [11].

10H-Quindoline, 11-methoxy (11-Methoxy-quindoline, 7). Yellow powder: Table 1. In agreement with literature [12].

10H-Quindoline (Quindoline, 8). Orange crystal. High Resolution Mass Spectrometry by Electronspray (HRESI) (+)-MS m/z 219.09 (calc. for $\mathrm{C}_{15} \mathrm{H}_{10} \mathrm{~N}_{2}: 218.08 \mathrm{~g} / \mathrm{mol}$ ). ${ }^{1} \mathrm{H}-\mathrm{NMR}\left(500 \mathrm{MHz}\right.$ ) (DMSO- $d_{6}$ ) $\delta$ : $7.63(\mathrm{~d}, J=10.0 \mathrm{~Hz}, 1 \mathrm{H}, \mathrm{H}-1), 7.39(\mathrm{td}, J=10.0 \mathrm{~Hz}, 1 \mathrm{H}, \mathrm{H}-2), 7.67$ (td, $J=10.0$ e $5.0 \mathrm{~Hz} 1 \mathrm{H}, \mathrm{H}-3), 8.29$ (d, $J=10.0 \mathrm{~Hz}, 1 \mathrm{H}, \mathrm{H}-4), 8.44(\mathrm{~d}, J=10.0 \mathrm{~Hz}, 1 \mathrm{H}, \mathrm{H}-6), 7.24(\mathrm{td}, J=10.0 ; 5.0 \mathrm{~Hz}, 1 \mathrm{H}, \mathrm{H}-7), 7.57(\mathrm{~m}, 2 \mathrm{H}, \mathrm{H}-8$ e $\mathrm{H}-9), 11.72(\mathrm{~s}, 1 \mathrm{H}, 10-\mathrm{NH})$ and $8.52(\mathrm{~s}, 1 \mathrm{H}, \mathrm{H}-11)$. In agreement with literature [12].

10H-Quindolinium, 5-methyl (Salt of cryptolepine, 9): NMR data published [5]. 


\subsection{Pharmacological Data}

The vasorelaxant activity of compounds 6 (quindolinone) and 9 (salt of cryptolepine) were evaluated by increasing cumulative addition of the compound $\left(10^{-12}-10^{-3} \mathrm{M}\right)$ using rodent mesenteric arteries pre-contracted with phenylephrine (PHE) $(1 \mu \mathrm{M})$. The experiments were carried out using arteries with functional endothelium and without functional endothelium (Figures 2 and 3). Data were expressed as maximum effect (Emax) and the potency of the drug was expressed as $\mathrm{pD}_{2}$, which is the $\log$ of the $50 \%$ of the effective concentration $\left(\mathrm{EC}_{50}\right)$.

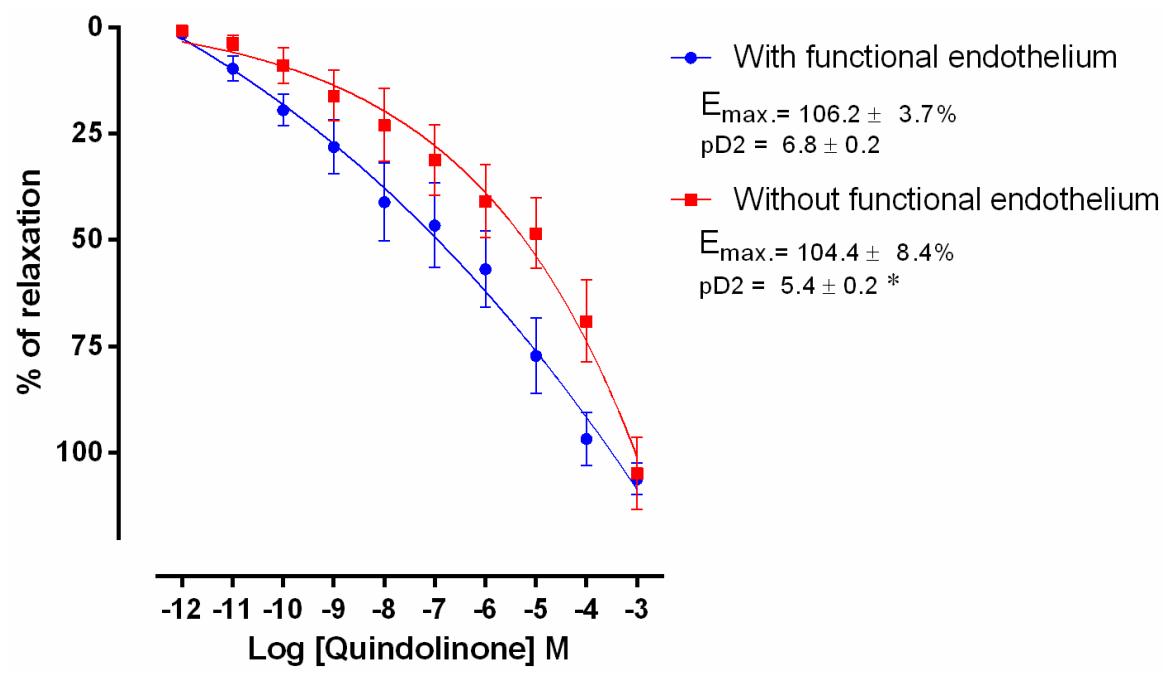

Figure 2. Concentration-response curve of quindolinone $\left(10^{-12}-10^{-3} \mathrm{M}\right)$ in cranial mesenteric artery rings isolated from rats with functional endothelium $(\bullet)$ and without functional endothelium ( $(\mathbf{\square})$ pre-contracted with phenylephrine $(\mathrm{PHE}, 1 \mu \mathrm{M})$. Values are expressed as mean \pm standard error of mean (SEM), ${ }^{*} p<0.05$ compared to the ring with functional endothelium.

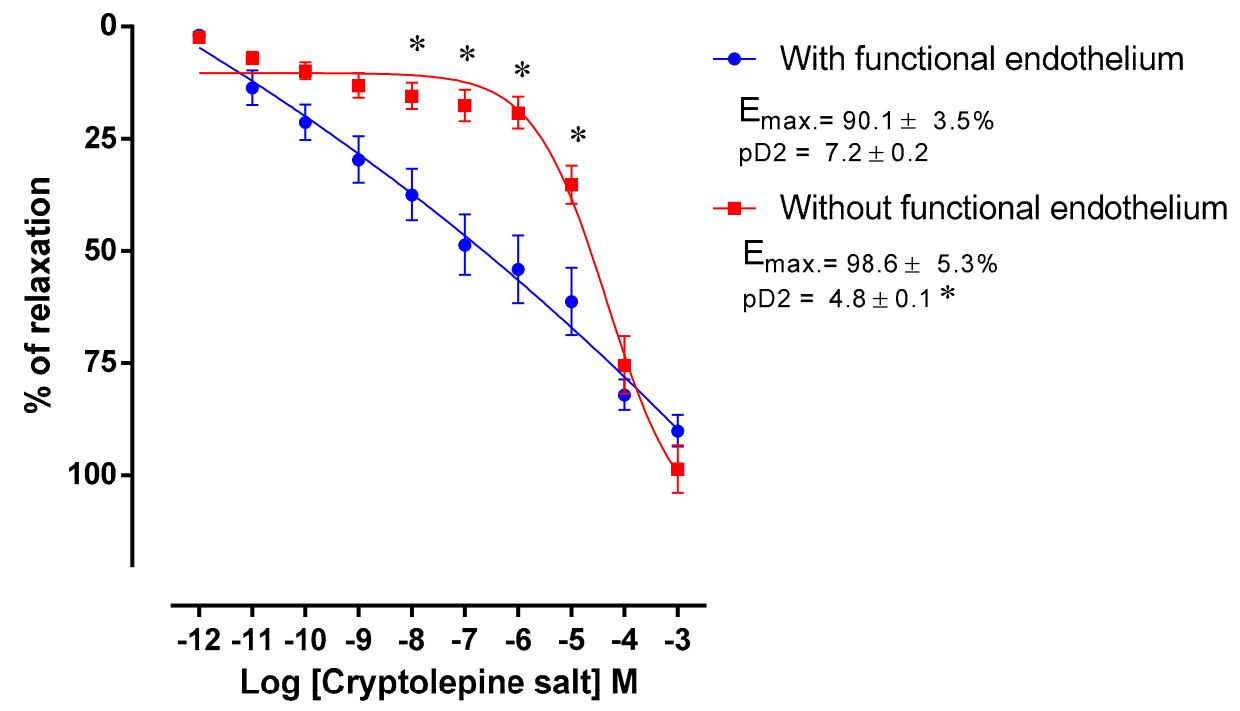

Figure 3. Concentration-response curve of cryptolepine salt $\left(10^{-12}-10^{-3} \mathrm{M}\right)$ in cranial mesenteric artery rings isolated from rats with functional endothelium $(\bullet)$ and without functional endothelium $(\boldsymbol{\square})$ pre-contracted with phenylephrine $(\mathrm{PHE}, 1 \mu \mathrm{M})$. Values are expressed as mean \pm standard error of mean (SEM), ${ }^{*} p<0.05$ compared to the ring with functional endothelium. 


\section{Discussion}

The ${ }^{1} \mathrm{H}-\mathrm{NMR}$ spectra of compound 7 showed signals with a pattern of substitution indicating an indoquinoline skeleton [5], aromatic rings ortho di-substituted with the presence of four broad doublets : $\delta_{\mathrm{H}} 8.37 \mathrm{~J}=7.85 \mathrm{~Hz}(\mathrm{H}-6) ; \delta_{\mathrm{H}} 8.30 \mathrm{~J}=8.45 \mathrm{~Hz}(\mathrm{H}-1) ; \delta_{\mathrm{H}} 8.18 \mathrm{~J}=8.5 \mathrm{~Hz}(\mathrm{H}-4) ; \delta_{\mathrm{H}} 7.64$ $J=7.1 \mathrm{~Hz}(\mathrm{H}-9)$, besides four broad triplets: $\delta_{\mathrm{H}} 7.70 \mathrm{~J}=7.45 \mathrm{~Hz}(\mathrm{H}-3) ; \delta_{\mathrm{H}} 7.63 \mathrm{~J}=7.6 \mathrm{~Hz}(\mathrm{H}-8) ; \delta_{\mathrm{H}} 7.58$ $J=7.55 \mathrm{~Hz}(\mathrm{H}-2) ; \delta_{\mathrm{H}} 7.30 \mathrm{~J}=7.0 \mathrm{~Hz}(\mathrm{H}-7)$ (Table 1$)$.

A singlet at $\delta_{\mathrm{H}} 11.50(1 \mathrm{H})$ was detected indicating the $\mathrm{N}-\mathrm{H}$ of indol $(\mathrm{NH}-10)$ found in this group of alkaloids [5]. The hydrogens at $\delta_{\mathrm{H}} 4.39(\mathrm{~s}, 3 \mathrm{H})$ were attributed to a methoxy group bonded to $\mathrm{C}-11$, since the chemical shift at $\delta_{\mathrm{H}} 9.02$ characteristic of $\mathrm{H}-11$ was not found [12].

The ${ }^{13} \mathrm{C}$-NMR data supported the proposal of indoquinoline nucleous for compound 7 by showing signals for 15 carbons. The chemical shift at $\delta_{C} 60.7$ indicated a methoxy group as proposed by ${ }^{1} \mathrm{H}-\mathrm{NMR}$, being confirmed by the HMQC (Table 1).

The HMBC spectrum of 7 allowed establishing the chemical shifts of C-4a, C-6a, C-9a, C-11, and C-11a. Relevant correlations could be seen between: H-3 and H-1 with C-4a $\left(J^{3}\right)$; H-9 with C-6a $\left(J^{3}\right)$; H-8 with C-9a $\left(J^{3}\right)$ and H-1 with C-9a $\left(J^{2}\right)$ (Table 1 and Figure 4).

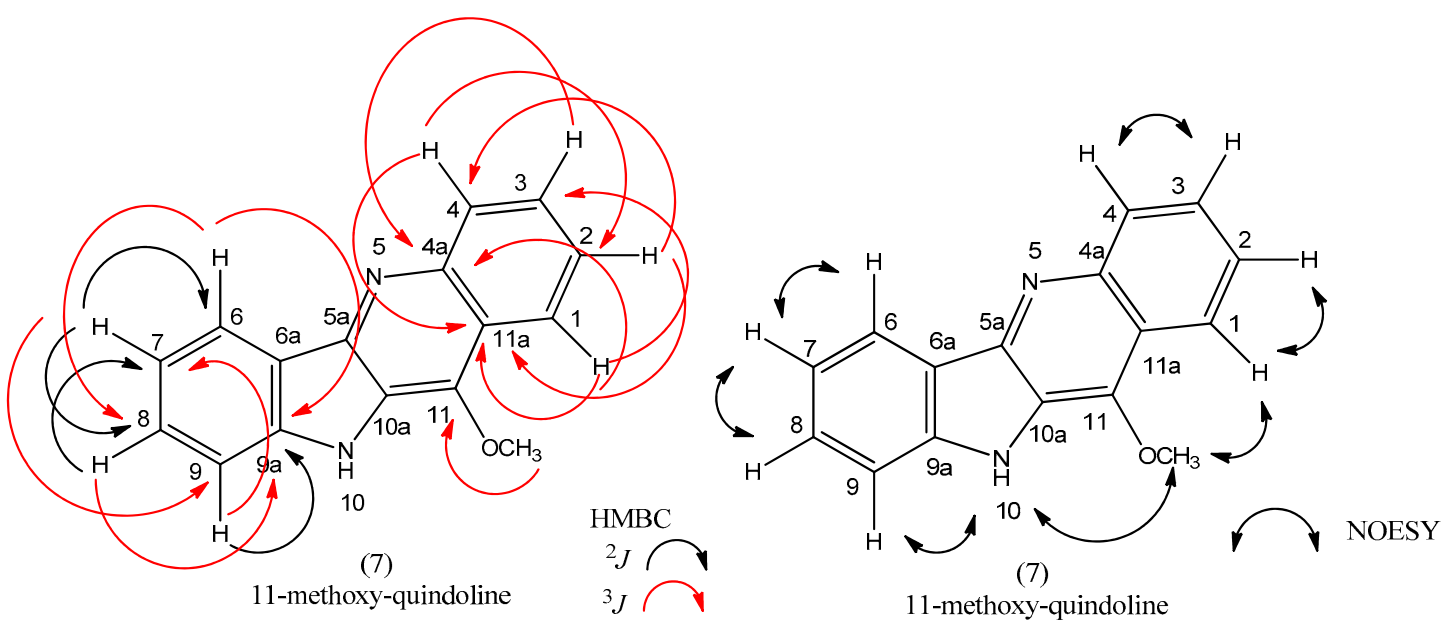

Figure 4. HMBC and NOESY correlations for compound 7.

The NOESY spectra of compound 7 showed correlations between neighbour hydrogens, as well as confirmed that the methoxy is bonded to $\mathrm{C}-11$, by showing correlation between $\delta_{\mathrm{H}} 4.39(\mathrm{O}-\mathrm{CH})$ with $\delta_{\mathrm{H}} 11.50(\mathrm{NH}-10)$ and $\delta_{\mathrm{H}} 8.30(\mathrm{~d}, \mathrm{H}-1)$.

The tested substances quindolinone (6) and the salt of cryptolepine (9) promoted vasorelaxation in mesenteric artery rings with functional endothelium and after endothelium removal. The PHE potency in promoting arterial contraction was significantly reduced by compounds 6 and 9 (quindolinone: $6.8 \pm 0.2$ vs. $5.4 \pm 0.2, p<0.05$ and salt of cryptolepine: $19.7 \pm 0.2$ vs. $4.77 \pm 0.1, p<0.05$ ) (Figures 2 and 3$)$.

PHE is an agonist of $\alpha 1$ - adrenergic receptors [13,14], whose are coupled to Gq/11 protein. Once activated, the receptors trigger the hydrolysis of phosphatidyl inositol 4,5-bisphosphate $\left(\mathrm{PIP}_{2}\right)$ into inositol 1,4,5-trisphosphate ( $\left.\mathrm{IP}_{3}\right)$ and diacylglycerol (DAG) by the action of phospholipase C- $\beta$ (PLC $\beta$ ). Then, the IP3 receptors at the sarcoplasmic reticulum are activated, releasing $\mathrm{Ca}^{2+}$ into the cytosol. DAG and the elevation of intracellular $\mathrm{Ca}^{2+}$ activate kinase proteins, including protein kinase C (PKC) in smooth muscle. It results in phosphorylation and inactivation of enzymes related to the contractile process, such as myosin light chain phosphatase (MLCP) [15,16].

After endothelium removal, the vasorelaxant effects of both tested compounds were significantly altered. The vascular endothelium secretes several biologically active substances, and many of them are active in vessels' muscle cells, modulating the vascular tone. The vasodilator mechanism of 
endothelium is mediated by endothelium-derived relaxing factor (EDRF), such as nitric oxide (NO), prostacyclin, bradykinin, endothelium-derived hyperpolarizing factor (EDHF), and metabolites of monooxygenases, among others [17-20]. On the other hand, the endothelium-derived constrictor factors (EDCF) promote contraction, i.e., angiotensin II, endothelin, vasoconstrictors prostanoids, and reactive oxygen species, such as superoxide anion [21,22].

Thus, the vasorelaxant activity of tested compounds seems to involve endothelium-derived substances, since the effect was decreased after the endothelium removal. However, the compounds also seem to act in smooth muscle cells, since in endothelium-free preparations it was possible to observe some vasorelaxant effect. The vasorelaxant effect of cryptolepinone isolated from S. rhombifolia has been previously reported [5].

\section{Materials and Methods}

\subsection{General}

Silica gel 60 (Merck, Rio de Janeiro, RJ, Brazil) 7734 (0.063-0.2 mm particle, 70-230 mesh), neutral alumina, Sephadex LH-20, and XAD-2 were used for the chromatographic procedures. ${ }^{1} \mathrm{H}-$ and ${ }^{13}$ C-NMR spectra were recorded on a Varian Oxford 200 NMR spectrometer (200/50 MHz, Varian, São Paulo, Brazil) and on a Varian 500 NMR spectrometer (500/125 MHz, Varian). Mass spectra were obtained on a Xevo ${ }^{\circledR}$ G2-XS QT of mass spectrometer (Waters, Campinas, Brazil).

\subsection{Collection, Extraction, and Isolation}

Sida rhombifolia was collected in Santa Rita city (PB, Brazil) in September 2008 and identified by Dr. Maria de Fátima Agra. A voucher specimen (Agra 7045) is kept at the herbarium Professor Lauro Pires Xavier (CCEN/UFPB). The dried and powdered aerial parts of the plant $(5.5 \mathrm{~kg})$ were extracted with $95 \% \mathrm{EtOH}(10 \mathrm{~L}$, room temperature) for $72 \mathrm{~h}$. The $\mathrm{EtOH}$ extract was concentrated under reduced pressure at $40{ }^{\circ} \mathrm{C}$, providing $570 \mathrm{~g}$ of crude ethanol extract (CEE).

The CEE of S. rhombifolia showed positive results when tested with Dragendorff, Bouchadart, and Mayer reagents for detection of alkaloids. Thus, the classic alkaloid extraction was performed using $100 \mathrm{~g}$ of the CEE.

The acid $\mathrm{CHCl}_{3}$ fraction (1.2 g) was subjected to silica gel column chromatography (CC) using hexane (Hex), dichloromethane $\left(\mathrm{CH}_{2} \mathrm{Cl}_{2}\right)$, and methanol $(\mathrm{MeOH})$, alone or in binary mixtures of increasing polarity, resulting in the isolation of compounds $\mathbf{1}(21 \mathrm{mg}), \mathbf{2}(9 \mathrm{mg})$, and $\mathbf{3}(8 \mathrm{mg})$. The total alkaloids fraction $(800 \mathrm{mg}$ ) was submitted to CC using neutral alumina as stationary phase. The column fraction 14/43 (28 mg) was chromatographed on preparative, Analytical Thin Layer Chromatography (TLC) using alumina and eluted with Hex:ethyl acetate (8:2), yielding the pure compounds 7 (12 mg) and 8 (5 mg).

Part of the CEE (200 g) was subjected to filtration under reduced pressure (VLC) using silica gel 60 as stationary phase and eluted with hexane (Hex.), ethyl acetate (EtOAc), and methanol (MeOH) alone or in binary mixtures increasing polarity.

An sample of the MeOH phase (10 g) was submitted to CC on XAD-2 using the eluents: $\mathrm{H}_{2} \mathrm{O}$, $\mathrm{H}_{2} \mathrm{O}: \mathrm{MeOH}$ (7:3), $\mathrm{H}_{2} \mathrm{O}: \mathrm{MeOH}$ (1:1), $\mathrm{MeOH}, \mathrm{Hex}$, acetone, and ethyl acetate (AcOEt). Fractions of MeOH (162 mg) and $\mathrm{H}_{2} \mathrm{O}: \mathrm{MeOH}(7: 3)(475 \mathrm{mg})$ were fractioned on a Sephadex LH-20 (MeOH) leading to isolation of compounds $4(5 \mathrm{mg})$ and $5(10 \mathrm{mg})$.

Another part of the CEE (200 g) was dissolved in EtOH- $\mathrm{H}_{2} \mathrm{O}$ (9:1) and submitted to liquid-liquid chromatography using $\mathrm{Hex}, \mathrm{CH}_{2} \mathrm{Cl}_{2}, \mathrm{EtOAc}$ and $n$-butanol, obtaining the respective phases. The $\mathrm{CH}_{2} \mathrm{Cl}_{2}$ phase (26 g) was chromatographed on VLC (silica gel 60) eluted with $\mathrm{CH}_{2} \mathrm{Cl}_{2}$ and $\mathrm{MeOH}$ alone and in mixtures increasing polarity. The fraction $\mathrm{CH}_{2} \mathrm{Cl}_{2}: \mathrm{MeOH}(9: 1)(7 \mathrm{~g})$ was chromatographed on silica gel CC using the same solvents. The fraction $66 / 74(85 \mathrm{mg})$ was purified on a Sephadex LH-20 $(\mathrm{MeOH})$ yielding compound $6(23 \mathrm{mg})$. 


\subsection{Biological Assay}

The experiments were approved by the Federal University of Paraíba Ethical Committee for Animal Use under the protocol CEPA\#305/09. After animal euthanasia by decapitation using a guillotine, the cranial mesenteric artery was isolated, placed in Tyrode's solution and dissected in order to make it free of adhering tissue. In endothelium-denuded experiments, endothelium was removed by rubbing the intimal surface of the vessels. Rings with 1-2 mm were obtained and placed in physiological Tyrode's solution, maintained to $37^{\circ} \mathrm{C}$, gassed with carbogenic mixture $\left(95 \% \mathrm{O}_{2}\right.$ and $5 \% \mathrm{CO}_{2}$ ), and kept at $\mathrm{pH} 7.4$. All preparations were stabilised under a resting tension of $0.75 \mathrm{~g}$ for $1 \mathrm{~h}$. The solution was replaced every $15 \mathrm{~min}$ in order to prevent the accumulation of metabolites. The force of contraction was isometrically recorded by a force transducer (Miobath-4, WPI, Sarasota, FL, USA) coupled to an amplifier-recorder (Miobath-4) and to a computer equipped with an analog-to-digital converter board as described earlier. The presence of functional endothelium was assessed by the ability of acetylcholine $(10 \mu \mathrm{M})$ to induce more than $80 \%$ relaxation of vessels pre-contracted with phenylephrine $(10 \mu \mathrm{M})$. Less than $10 \%$ of relaxation to acetylcholine was taken as evidence that the vessel segments were functionally denuded of endothelium [5]. The preparations were exposed to cumulatively concentrations of tested compounds $\left(10^{-12}-10^{-3} \mathrm{M}\right)$ added to the preparations until a maximum response was observed as indicated by a plateau response (approximately $3-5 \mathrm{~min}$ ).

\subsection{Statistical Analysis}

The results were expressed as mean \pm standard error of the mean (SEM). Differences between means were considered significant when $p<0.05$. Statistical comparisons between two variables were performed by using Student's $t$-test unpaired. The results were analyzed and plotted using GraphPad Prism 5.0 software (GraphPad Software, San Diego, CA, USA).

\section{Conclusions}

The study of S. rhombifolia aerial parts, using chromatographic and spectroscopic techniques, led to the identification of eight substances, among them two coumarins: scopoletin (1) and escoporone (2); a ferulic acid derivative, ethoxy-ferulate (3); two flavonoids: kaempferol (4) and kaempferol-3-O- $\beta$-D-glycosyl- $6^{\prime \prime}-\alpha$-D-rhamnose (5); and three indoquinoline alkaloids: quindolinone (6), 11-methoxy-quindoline (7) and quindoline (8). Compound 3 is being first reported in the Sida genus, and others have been previously reported strengthening Sida chemosystematics [23-25].

The quindolinone (6) and the salt of cryptolepine (9) induced vasorelaxation dependent on the vascular endothelium, justifying the use of the species in popular medicine in India. The vasorelaxation effect may be related to indoquinoline core, but more protocols are required to elucidate their complete mechanism of action.

Acknowledgments: The authors are grateful to National Counsel of Technological and Scientific Development (CNPq) and Foundation for Science and Technology Support of Pernambuco (FACEPE) for financial support, to Federal University of Paraiba (UFPB) for technical assistance, to the Center of Characterization and Analysis Central analytic multiuser laboratory-UFPB (LMCA-UFPB) for obtaining the spectra.

Author Contributions: O.S.C., Y.C.F.T., M.F.V.d.S. isolated and identified the compounds; T.M.S.S. obtained spectra; M.F.A. collected and identified the plant; M.M.d.O.M., L.d.G.M.J. and V.d.A.B. performed the biological assay.

Conflicts of Interest: The authors declare no conflict of interest.

\section{References}

1. Carvalho, P.E.R.; Gaiad, S. Árvore do Conhecimento Espécies Arbóreas Brasileiras. Agencia Embrapa de Informação Tecnológica (AGEITEC). EMBRAPA 2015. Available online: http:/ / www.agencia.cnptia.embrapa. br/gestor/especies_arboreas_brasileiras/arvore/CONT000fu1ekyj602wyiv807nyi6s9rqihfq.html (accessed on 29 December 2016). 
2. Bovini, M.G.; Esteves, G.; Duarte, M.C.; Takeuchi, C.; Kuntz, J. Malvaceae in Lista de Espécies da Flora do Brasil; Jardim Botânico do Rio de Janeiro: Rio de Janeiro, Brazil, 2015.

3. Bovini, M.G. Sida in Lista de Espécies da Flora do Brasil; Jardim Botânico do Rio de Janeiro: Rio de Janeiro, Brazil, 2015.

4. Dinda, B.; Das, N.; Dinda, S.; Dinda, M.; Silsharma, I. The genus Sida L. a traditional medicine: Its ethnopharmacological, phytochemical and pharmacological data for commercial exploitation in herbal drugs industry. J. Ethnopharmacol. 2015, 176, 135-176. [CrossRef] [PubMed]

5. Chaves, O.S.; Gomes, R.A.; Tomaz, A.C.A.; Fernandes, M.G.; das Graças Mendes Junior, L.; de Fátima Agra, M.; Braga, V.A.; Souza, M.F.V. Secondary Metabolites from Sida rhombifolia L. (Malvaceae) and the Vasorelaxant Activity of Cryptolepinone. Molecules 2013, 18, 2769-2777. [CrossRef] [PubMed]

6. Thounaojam, M.C.; Jadeja, R.N.; Ansarullah; Patel, V.B.; Devkar, R.V.; Ramachandran, A.V. Potential of Sida rhomboidea. Roxb Leaf Extract in Controlling Hypertriglyceridemia in Experimental Models. Pharmacognosy Res. 2009, 1, 208-212.

7. Monsef-Esfahani, H.R.; Amini, M.; Goodarzi, N.; Saiedmohammadi, F.; Hajiaghaee, R.; Faramarzi, M.A.; Tofighi, Z.; Ghahremani, M.H. Coumarin compounds of Biebersteinia multifida roots show potential anxiolytic effects in mice. J. Pharm. Sci. 2013, 21,1-8. [CrossRef] [PubMed]

8. Silva, D.A.; Silva, T.M.S.; Lins, A.C.S.; Costa, D.A.; Cavalcante, J.M.S.; Matias, W.N.; Braz-Filho, R.; Souza, M.F.V. Constituintes Químicos e Atividade Antioxidante de Sida galheirensis Ulbr. (Malvaceae). Quím. Nova 2006, 29, 1250-1256. [CrossRef]

9. Pizzallotti, M.G.; Cunha-Junior, A.; Szpoganicz, B.; Sousa, E.; Braz-Filho, R.; Schripsema, J. Flavonóides glicosilados das folhas e flores de Bauhina forficata (Leguminosae). Quím. Nova 2003, 26, 466-469. [CrossRef]

10. Nogueira, T.B.S.S.; Nogueira, R.B.S.S.; Silva, D.A.; Tavares, J.F.; Lima, E.O.; Pereira, F.O.; Fernandes, M.M.M.S.; Medeiros, F.A.; Sarquis, R.S.F.R.; Braz-Filho, R.; Souza, M.F.V. First Chemical Constituents from Cordia exaltata Lam and Antimicrobial Activity of Two Neolignans. Molecules 2013, 18, 11086-11099. [CrossRef] [PubMed]

11. Lavrado, J.P.M.F. Novel C11 Amino Derivatives of Cryptolepine. Ph.D. Thesis, Universidade de Lisboa, Lisboa, Portugal, 2010.

12. Paulo, A.; Gomes, E.T. New alkaloids from Cryptolepis sanguinolenta. J. Nat. Prod. 1995, 58, 485-1491. [CrossRef]

13. Bylund, D.B. Subtypes of $\alpha 1$ - and $\alpha 2$-adrenergic receptors. FASEB J. 1992, 6, 832-839. [PubMed]

14. Büscher, R.; Herrmann, V.; Ring, K.M.; Kailasam, M.T.; O'Connor, D.T.; Parmer, R.J.; Insel, P.A. Variability in phenylephrine response and essential hypertension: A search for human $\alpha_{1 \mathrm{~B}}$-adrenergic receptor polymorphisms. J. Pharmacol. Exp. Ther. 1999, 291, 793-798. [PubMed]

15. McCarron, J.G.; Bradley, K.N.; MacMillan, D.; Muir, T.C. Sarcolemma agonist-induced interactions between InsP3 and ryanodine receptors in $\mathrm{Ca}^{2+}$ oscillations and waves in smooth muscle. Biochem. Soc. Trans. 2003, 31, 920-924. [CrossRef]

16. Thorneloe, K.S.; Nelson, M.T. Ion channels in smooth muscle: regulators of intracellular calcium and contractility. Can. J. Physiol. Pharm. 2005, 83, 215-242. [CrossRef] [PubMed]

17. Furchgott, R.F.; Zawadzki, J.V. The obligatory role of endothelial cells in the relaxation of arterial smooth muscle by acetylcholine. Nature 1980, 288, 373-376. [CrossRef] [PubMed]

18. Palmer, R.M.J.; Ferrige, A.G.; Moncada, S. Nitric oxide release accounts for the biological activity of endothelium-derived relaxing factor. Nature 1987, 327, 524-526. [CrossRef] [PubMed]

19. Moncada, S.; Palmer, R.M.J.; Higgs, E.A. Nitric oxide: Physiology, pathophysiology and pharmacology. Pharmacol. Rev. 1991, 43, 109-142.

20. Cooke, J.P.; Dzau, V.J. Derangements of the nitric oxide synthase pathway, arginine and cardiovascular disease. Circulation 1997, 96, 379-382. [PubMed]

21. Félétou, M.; Vanhoutte, P.M. The alternative: EDHF. J. Mol. Cell. Cardiol. 1999, 31, 15-22. [CrossRef]

22. De Vriese, A.S.; Verbeuren, T.J.; van de Voorde, J.; Lameire, N.H.; Vanhoutte, P.M. Endothelial dysfunction in diabetes. Br. J. Pharmacol. 2000, 130, 963-974. [CrossRef] [PubMed]

23. Chen, W.Q.; Zhang, H.; Xu, H.H. Bioactivity and chemical constituents of Sida rhombifolia. Nongyaoxue Xuebao 2012, 14, 377-382.

24. Ahmed, F.; Toume, K.; Ohtsuki, T.; Rahman, M.; Sadhu, S.K.; Ishibashi, M. Cryptolepine, Isolated from Sida acuta, Sensitizes Human Gastric Adenocarcinoma Cells to TRAIL-induced Apoptosis. Phytother. Res. 2011, 25, 147-150. [CrossRef] [PubMed] 
25. Karou, S.D.; Nadembega, W.M.C.; Ilboudo, D.P.; Ouermi, D.; Gbeassor, M.; de Souza, C.; Simpore, J. Sida acuta Burm. f.: A medicinal plant with numerous potencies. Afr. J. Biotechnol. 2007, 6, 2953-2959.

Sample Availability: Samples of all isolated compounds are available from the authors. 